\title{
Price Tactics For A Turbulent Environment: A Complexity Theory View
}

\author{
Roger B. Mason, Durban University of Technology, South Africa
}

\begin{abstract}
This paper proposes that pricing tactics are influenced by the nature of the external environment. It illustrates the pricing tactics suggested for a turbulent, versus a stable, environment, when viewed through a complexity theory lens. A qualitative, case method, using depth interviews, investigated the pricing tactics in four firms to identify the tactics adopted in more successful, versus less successful, firms in turbulent versus stable environments. The results partially confirmed that the use of destabilizing pricing tactics can be helpful in a turbulent market, while stabilizing tactics can be helpful in a stable market. However, the effect of such tactics on business performance was not clear. These findings will benefit marketers by emphasizing a new way to consider future pricing activities. How this approach can assist marketers, and suggestions for further research, are provided. Since businesses and markets are complex adaptive systems, using complexity theory to understand how to cope in turbulent environments is necessary but has not been widely researched. Therefore, this paper can be seen as a foundation for research using complexity theory to better understand pricing tactics in turbulent environments.
\end{abstract}

Keywords: Complexity Theory; Chaos Theory; Marketing Mix; Marketing Tactics; Price, Pricing; Turbulent Environment; Turbulence

\section{INTRODUCTION}

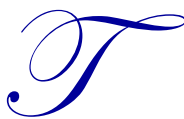

he levels of turbulence in South Africa over the past twenty years have increased considerably. At the macro level, Burgess (1998) showed how the Indian Ocean Rim area (of which South Africa is part) changed rapidly, with the competitive environment increasing in turbulence. At the micro level, Van der Walt et al. (1996) maintained that lifestyles, values and expectations of South African society had changed perceptibly in the previous twenty years, while Joubert (1998) illustrated this turbulence by highlighting the forces that influenced the decline in the value of the Rand from 1994, including changing mix of political, legal, economic and socio-cultural factors on the South African environment. Other authors, such as Weeks (2007), Morris and Schurink (1993) and Morris et al. (1996), all showed South Africa as having an increasingly turbulent external environment.

As a result, South Africa is a suitable context for examining environmental turbulence. Relatively little complexity-based research has been done in the field of management, marketing and pricing, and especially in South Africa (Schindehutte \& Morris, 2001; Khouja et al., 2008). The importance of this is stressed by Macias and Guitart (2011) who highlight the large number of factors that influence pricing, especially in a turbulent environment. Pricing is thus a complex decision-making process, illustrated by Zaib et al. (2013) via a causal loop diagram, and by Chen and Ma (2013) via research into pricing in supply chains in many industries

The purpose of this study was to add to the marketing and complexity literature by investigating the pricing tactics suggested for turbulent environments, versus those suggested for stable environments. This was applied via a multiple case study, exploratory approach in South Africa - a developing country with many industries experiencing extreme complexity and turbulence.

The paper starts with a brief overview of complexity theory, followed by a short justification of South Africa as a turbulent environment. Then the traditional methods of handling pricing, followed by the methods 
suggested by complexity theory, are discussed. Methods for the empirical case study are provided, followed by a discussion of the main findings of the study. Implications for marketers and the study's limitations and recommendations are given.

\section{LITERATURE REVIEW}

\section{Complexity Theory}

The main idea of complexity "is that all things tend to self-organize into systems" when simple rules are applied (Kelly \& Allison, 1999: 5). These systems can produce unexpected behaviors (Manuj and Sahin, 2011) because of non-linear feedback (Stacey, 1996) and because the system's parts interact with each other (Meade \& Rabelo, 2004). Complex behavior is orderly, yet full of surprise; uncontrollable, yet not totally chaotic. This behavior is not enforced by a 'manager' and cannot be predicted from any single part of the system and so cannot be controlled (Wu \& Zhang, 2007). Five concepts define complexity:

- $\quad$ The central concept of complexity is self-organization, the process of order emerging from simple rules in a system, which is not controlled by a 'manager' (Holbrook, 2003), and which results in innovative responses emerging (Dolan et al., 2003).

- $\quad$ This emergence, the second concept, happens when the system changes, leading to disorder and preventing the system from ossifying. Emergence happens at the edge-of-chaos, enabling new actions to emerge.

- $\quad$ The third concept is feedback. Negative feedback damps change, pushing towards equilibrium (Stacey, 1995), while positive feedback amplifies small changes, pushing towards chaos (Doherty \& Delener, 2001). Together, they balance the system at the 'edge-of-chaos', the best position for turbulent environments (Doherty \& Delener, 2001).

- $\quad$ The fourth concept is sensitive dependence on initial conditions. In stable systems, small changes have small effects, but in turbulent systems, small changes can grow exponentially, making long-term prediction impossible (Holbrook, 2003; Wu \& Zhang, 2007; Chen \& Ma, 2013). Small nudges can lead to major changes, with patterns and clues indicating which changes to 'nudge' (Morrison \& Quella, 1999).

- $\quad$ These patterns, known as attractors, are the fifth concept. The edge-of-chaos attractor, known as a 'strange attractor', reflects the area of maximum creativity and innovation. A strange attractor stays within certain boundaries (Holbrook, 2003) - how the system will develop cannot be predicted, but it will not go outside its attractor (Doherty \& Delener, 2001). Thus, the attractor allows change while maintaining some order.

\section{Traditional Pricing Methods}

Traditionally, managers see that the main function of pricing is to cover costs and provide a reasonable rate of return. Furthermore, most firms charge about the same, with regulatory bodies limiting the use of price as a weapon. Price setting is also often based on anecdotal opinions of a few sales people or managers (Eugster et al., 2000), or managers rely on "simplistic rules of thumb and ... cost-based formulas" (Pitt et al., 1997: 2), which are suitable in simple and stable environments. Morris and Schurink (1993) found that managers handle price in uncertain environments conservatively by adopting risk minimization strategies, which are reflected in cost-based pricing or formulae approaches and by inflexible and uncreative pricing. There seems to be little difference between pricing for stable versus turbulent environments. It is probable that conservative pricing approaches in complex and turbulent environments do not contribute significantly to marketing success. This is supported by Morris and Schurink (1993) who believe that traditional cost-based pricing formulae are unable to produce the flexible, complex and quick pricing responses required in a turbulent environment. These traditional methods are also unsuitable due to the increasing complexity of price management caused by micro-segmentation and the proliferation of products and channels which need, in some cases, millions of price points to be managed (Bright et al., 2006). Schindehutte and Morris (2001) also stress the need for new approaches for price determination in turbulent markets.

\section{Application Of Complexity Theory To Pricing}

There is a history of research on pricing, using chaos and complexity, going back thirty years - Jensen and Urban (1984) showed that pricing can generate complex behavior, including strange attractors. Jager (2007) 
supports the use of a non-linear, complexity approach in volatile, complex markets. Priesmeyer (1992) maintains that supply and demand, when viewed from a non-linear perspective, do not operate as traditionally believed - sales can increase when prices are increased and decrease when prices are reduced. The key is that the equilibrium point acts as an attractor. Within the attractor's boundaries, there are equilibrium points at which high demand and high prices occur and points at which low prices and low demand occur. Therefore, understanding a product's attractor is helpful as it affects price changes and can guide price change timing. This relevance of chaos and complexity to pricing is supported by Mix (1993) who believes that price dynamics reflect chaos, by Granovetter and Soong (in Hibbert \& Wilkinson, 1994) who argue that price changes affect market dynamics, and by Khouja et al. (2008) who suggest agent-based models and complex adaptive systems for optimizing pricing decisions and prices. Priesmeyer (1992) found that the level of chaos is important - demand was not influenced by price cuts when low order chaos (less turbulent) was present, but demand was influenced by price cuts when high order chaos (more turbulent) was present. This implies that destabilizing tactics are more effective the more turbulent the environment is.

Anticipation and quick reactions appear to be important in turbulent markets. Smith et al. (1999) believe that firms in turbulent environments can benefit by reacting quickly to competitive price changes, but in low turbulence markets, the ease of access to pricing information has led to power shifting from seller to buyer, resulting in an inability to increase prices. Samli (1993) supports this, saying that proactive pricing in turbulent times is essential.

As mentioned above, availability of pricing information in stable markets limits a marketer's ability to set prices. Freely available price information and digital technologies enable customers to search for products at the price they require. Various simulations show chaos and complexity in electricity pricing (Kř́ž \& Kratochvil, 2014) and in pricing in retailing and recycling supply chains (Ma \& Chen, 2014). Thus, it can be seen that standard pricing policies and fixed prices are not suitable for turbulent markets.

Since price is so critical to marketing performance, care must be taken in setting prices. Chen and Ma (2013) note that decision variables taken too quickly can push the system into chaos - special deals offered by consumer marketers have increased complexity and consumers are encouraged to buy on price (Schiller et al., 1996). Samli (1993) stresses sensitivity to price elasticity because destabilizing pricing, such as cutting prices in an inelastic market, may not lead to increased sales. In addition, Smith et al. (1999) found that spending on product improvements might not justify higher prices while in a stable market, prices may be increased without a matching performance increase. These findings suggest different pricing policies according to environmental turbulence.

From the above discussion, it can be concluded that proactive price tactics are important in a complex and turbulent environment. Prices can be used to influence a market, but pricing needs to be quick and specific to the customer. Standardized, fixed prices are no longer adequate.

\section{Pricing Methods Suggested By Complexity Theory}

Pricing can be used both as a stabilizing and a destabilizing tactic. Status quo pricing strategies, for example, attempt to maintain the market pricing system at equilibrium, while dramatic price changes can disturb the system and change the nature of market demand. Priesmeyer (1992) argues that, from a non-linear perspective, supply and demand do not always operate as traditionally believed. Therefore, understanding a product's attractor is helpful.

Nilson (1995: 41) says the 'nudge' effect, or sensitive dependence on initial conditions, can be used to encourage a market to "change not in a random way but in a desired direction", e.g. a firm cuts price to increase sales - competitors follow suit and a price war results. If this gets a positive response from the market (a positive feedback loop), it may result in the market restructuring, an unanticipated result. But a firm understanding the nonlinear nature of these actions would be prepared for the unexpected and could take advantage of the restructuring better than its competitors, thereby building a competitive advantage. Thus, managers who understand the nonlinear nature of pricing can use it as an effective tactic to create their own environment. Pricing as a tactical tool is also important because, through sophisticated pricing structures, firms can customize prices to suit individual segments or customers. This develops relationships and better caters to the needs of different clients (Pitt et al., 
1997). Thus, success in turbulent environments comes from adopting pricing strategies that are novel and innovative.

The above discussion implies that using pricing as a destabilizing tactic is beneficial in a turbulent environment. Morris and Schurink's (1993) findings on the South African environment confirmed that pricing tended to be more market-based and firms did use some aggressive pricing tactics. They also found that these pricing approaches were more prevalent in complex and turbulent environments. This situation, they believe, requires pricing managers to become more externally focused and to develop more offensive and opportunistic pricing systems. This tactic is important because those firms that could cope with increasing complexity would be more successful.

The use of aggressive pricing strategies is likely to destabilize the marketing system, especially if the environment is price focused. Nilson (1995:122) maintains that "...the greater the amount of product sold on price promotions in a market, the more disloyal will the customers be and the more unstable will the market system be." Therefore, in a price-oriented market, aggressive price promotions can win short-term sales. However, if a firm introduces 'everyday-low-prices' in such a market, it may lose sales unless it also introduces stabilizing tactics. Pitt et al. (1997: 6) maintain that competitor hostility leads to be more price competition. This is more than mere price cutting and includes greater creativity in pricing, e.g. "charging price differentials to different market segments, varying price based on time of consumption, various time payment schemes and creative discount structures." Other short-term tactics, such as rebates, coupons and cents-off deals, create strategies that are more innovative, flexible and proactive. This means that price can be "an adaptive means for addressing and capitalizing on increasingly complex change in the external environment" (Schindehutte \& Morris, 2001:47) and shows that they see aggressive pricing in a more positive light than Nilson (1995), who agrees that it is important, but does not really recommend it.

Types of price setting also appear to differ in complex and turbulent markets. For example, Pitt et al. (1997) found more complex price setting and Roberts (2000) found an increase in differentiated pricing, with specific prices being set for individual customers. Kumar et al. (2000) found that prices were set differently to traditional pricing policies - either much lower or much higher, but in both cases with a superior value proposition. Mohr (2001) sees even more significant differences in price setting in 'high tech' markets. Because many 'high tech' products do not reach maturity (because of short product life cycles), it is not possible to price according to economies of scale. Thus, many innovative firms price very low, or even free, and rely on profits from upgrades, service, installations and complementary products. Pricing in such a turbulent environment is uncertain and risky, so understanding a product's attractor and pricing according to the attractor boundaries is important (Priesmeyer, 1992).

include:

Other aspects of pricing in a turbulent environment that might be important to a marketing manager

- $\quad$ Pricing should be flexible and adaptive to cope with, adapt quicker to, and capitalize on, environmental changes (Pitt et al., 1997; Macias \& Guitart, 2011).

- $\quad$ Firms in 'high tech' markets are less susceptible to having prices negotiated downwards, due to buyers not being able to gauge true costs (Smith et al., 1999).

- $\quad$ Many of the above authors imply that price leadership leads to success in turbulent markets (Morris and Schurink, 1993; Nilson, 1995; Pitt et al., 1997; Kumar et al., 2000).

A final reason for the importance of pricing as a market tactic, especially as a destabilizing one, is that it is a very visible decision variable ( Pitt et al., 1997; Schindehutte \& Morris, 2001). Prices send clear signals to the market about product value and firm objectives, and frequent price changes indicate that this is an innovative firm.

\section{METHODOLOGY}

The objective of the study was to investigate the types of pricing tactics adopted in turbulent/complex, versus those in stable/simple, industries and their relevance to success. In other words, is there a relationship between pricing tactics and success in a turbulent environment? To answer this question, the literature findings were 
summarized to develop models of the price tactics to be expected of more and less successful firms in complex/turbulent and simple/stable markets (Mason, 2004). These models are presented in Tables 2 and 3, respectively. Also based on literature, four propositions were developed to compare empirical findings against the models:

P1: A more successful firm in a complex/turbulent industry uses destabilizing price tactics.

P2: In a complex/turbulent industry, a less successful firm uses stabilizing price tactics.

P3: A more successful firm in a simple/stable industry uses stabilizing price tactics.

P4: In a simple/stable environment, a less successful firm uses destabilizing price tactics.

Due to the paucity of complexity research in this field (Khouja et al., 2008), a qualitative, exploratory case study approach was chosen (Gerschberger et al., 2012). The research was conducted in South Africa, which is a good 'turbulence laboratory' (Morris et al., 1996; Joubert, 1998). Two firms each in a simple/stable industry and a complex/turbulent industry were selected using maximal variation sampling through a two-stage process:

- $\quad$ First, the information technology (IT) industry was selected as most complex/turbulent and packaging as the most simple/stable, via a questionnaire posted to experts - industry analysts and management consultants.

- In each industry, more and less successful firms were chosen. A Delphi process with a panel of industry consultants, journalists and buyers assessed "success" in terms of 3 to 5 -year performance, with more successful meaning consistent sales, profits and market share growth, or good adaptation to changing environments. Less success meant poorer performance on these factors. The panel named CA as more, and $\mathrm{CB}$ as less, successful in the IT industry and PA as more, and PB as less, successful in packaging. To obtain co-operation, anonymity was promised, thus the artificial names of CA, CB, PA and PB. Table 1 provides a profile of the four firms.

Table 1: Profile Of Sample Firms

\begin{tabular}{cl}
\hline Firm & \multicolumn{1}{c}{ Characteristics } \\
\hline CA & $\begin{array}{l}\text { Large, listed on stock exchange, operates nationally, regionally and internationally. Emphasis is on hardware and } \\
\text { software. }\end{array}$ \\
CB & $\begin{array}{l}\text { Medium to large, listed on stock exchange, trades nationally, regionally and some international. Focus on software. } \\
\text { Medium subsidiary of larger group, trades nationally - focus on flexible packaging, especially for the }\end{array}$ \\
PA & $\begin{array}{l}\text { Lood/beverage industry. } \\
\text { Long established family business, trades nationally - focus on wide range of packaging applications, especially } \\
\text { pharmaceutical. }\end{array}$ \\
\hline
\end{tabular}

Using an interview guide, data were collected from 31 directors, managers and staff via depth interviews, which were audiotape recorded. Notes were taken and firm documents analyzed (e.g. annual reports, brochures, web pages, advertisements, minutes, manuals). To obtain the firms' co-operation, anonymity was assured.

Analysis was via thematic coding, using NVIVO software to deconstruct and reconstruct the transcripts, categorizing findings according to the two perspectives being studied (stable/turbulent and more/less successful). Manual content analysis summarized the field notes and documents for comparison with the research propositions. These analyses were then used to compare the two firms in each industry against each other and against the proposals and to compare the firms similar in success to each other and against the proposals.

'Method-appropriate criteria' and multiple data collection methods; namely, data triangulation, methodological triangulation, prolonged engagement and an audit trail, validated the procedures, ensuring rigor and trustworthiness (Flick, 1998). Construct validity was increased by using multiple data sources, internal validity by comparison and pattern matching across the cases, external validity by using cross-case analysis of multiple cases (allowing some generalization), and reliability by using a data collection protocol, a database of data and a chain of evidence (Yin, 2003). This method met the criteria for a high quality, rigorous and trustworthy study. 


\section{FINDINGS}

Pricing, and how the firms set and change prices, whether they use pricing aggressively as a tactic to achieve leadership or whether they adopt status quo pricing to maintain stability in their markets, is discussed in this section.

\section{Turbulent And Complex Environment}

Neither firm uses aggressive pricing as a regular strategy to disrupt markets. CA does not need to use aggressive pricing because their product offering has greater added value than their competitors' offerings do, which means lower prices are less important. However, there are situations in which both firms use pricing aggressively; for example, to win specific business or customers. Regarding CA, this was not as expected - more aggressive and destabilizing pricing was anticipated. The findings were, however, consistent with the expectations for a less successful firm (CB). Both firms appear to have fairly simple and easy to understand price-setting methods. In both firms, these methods are fairly standardized and so their base prices are much the same for all customers. However, each customer ends up with a different price because of different sizes of business and service levels. Surprisingly, CB appears to be more innovative in their pricing than CA. As can be expected from a market leader with the above pricing policies, $\mathrm{CA}$ achieves a price premium for their offerings. $\mathrm{CB}$, on the other hand, did not get a premium price and often have to accept prices being negotiated downwards to get the business. Although CA usually gets a premium, there are situations in which they do negotiate and cut prices. Neither firm can be said to be a price leader, as their supply partners indirectly set prices which they follow. Because neither firm has full control of its pricing, they are not able to be proactively aggressive with their pricing tactics.

Certain differences between the two firms exist, e.g. CAs are marginally less aggressive than CB, but are able to justify a premium more easily, contrary to expectations. Also, what was unexpected was $\mathrm{CB}$ being marginally more innovative in their pricing than CA. This may be necessary because of the inability to command premiums or to be able to control their own pricing 'fate'. The other aspects of pricing; namely, the basic pricesetting methods, standardization, and customers getting different prices, were similar for both firms. Overall these findings show that CA performs more like a less successful firm, while CB also exhibited behavior typical of a less successful firm.

\section{Stable And Simple Environment}

The two firms differ in their perception of the importance of pricing. PA sees pricing as less important because of value and quality, but PB sees it as very important. Neither firm uses pricing aggressively to upset the market or to win customers, nor do they use price-cutting as a weapon, but try to stabilize the market through their pricing. Thus, price changes are in reaction to other marketing activities and not a proactive pricing action. PA pricing is fairly conservative - not aggressive/disruptive; they tend to get business because of quality and not by price-cutting. $\mathrm{PB}$, though, appears to be prepared to cut prices reactively to keep business or regain lost business. PA, thus, does not use pricing tactically, while PB only uses it in reaction to someone else's aggression. Price setting by both firms is simple, but PB's actual setting process appears to be quite complex. The price-setting approach appears to be fairly traditional and not innovative. Both firms appear to be fairly flexible in determining prices, but PA is more fixed in their costing, while PB is more innovative. Both firms do seem to get premium prices, but only in specific market niches. Neither PA nor PB appears to be able to get a premium price for most of their products/services. Thus, it is not surprising to find that both firms have to negotiate lower prices with many customers. A slight difference between the two firms was found in terms of price leadership. PA tends toward being leaders, but only in their niche, while PBs are price followers. PA's conservative and non-aggressive approach to pricing and PB's following the pricing trends set by their competitors in their market, indicates that neither are price leaders.

Most of the pricing factors are similar between the two firms, which indicates they both may be merely following industry norms and conventions. The differences between the two firms involved the perceived importance of pricing (consistent with expectations) and price leadership (PB's lack of leadership not anticipated). The findings for PA are fairly consistent with what was expected for a more successful firm in a stable and simple 
market, but PB's findings are the reverse of what was expected. The main reason for this was the fact that they try to maintain reasonably high price levels but then have to react when more aggressive competitors undercut them.

\section{DISCUSSION}

From the above analysis, it appears as if the nature of the environment is not a determinant of success. To examine this further, the main findings were summarized and compared against the two pricing models and the propositions.

\section{Model 1 - Pricing Tactics For Complex/Turbulent Markets}

Aggressive pricing tactics, especially price cutting and the use of price as a promotional tool, are proposed by Model 1 to be important in complex/turbulent environments. Nilson (1995) suggests that aggressive pricing destabilizes markets and Pitt et al. (1997) suggest that creativity in pricing is necessary in complex/turbulent markets. Complex methods of price setting, usually with customized pricing, are used in complex/turbulent environments (Pitt et al., 1997; Roberts, 2000; Kumar et al., 2000) and successful firms in such markets tend to be price leaders (Morris and Schurink, 1993; Nilson, 1995; Pitt et al., 1997; Kumar et al., 2000). This approach enables more successful firms to obtain price premiums in complex/turbulent markets (Smith et al., 1999). Table 2 illustrates Model 1 in columns 1 and 2. As specified in the propositions, the more successful firm (CA) in a complex/turbulent market should closely match Model 1, whereas the less successful firm (CB) would not match Model 1 (propositions 1 and 2, respectively).

Table 2: Comparison Of Firms Ca And Cb Against Complex/Turbulent Environment Model

\begin{tabular}{|c|c|c|c|c|c|}
\hline \multicolumn{6}{|c|}{ More Success In Complex/Turbulent Environment } \\
\hline & Model 1 & Firm CA & Match & Firm CB & Match \\
\hline $\begin{array}{l}\text { Aggressive } \\
\text { pricing }\end{array}$ & $\begin{array}{l}\text { Aggressive price promotions } \\
\text { especially in hostile } \\
\text { competition and price focused } \\
\text { markets. }\end{array}$ & $\begin{array}{l}\text { Not used, emphasize value for } \\
\text { money. May use to win a } \\
\text { specific customer. }\end{array}$ & Partial & $\begin{array}{l}\text { Not used. Would only } \\
\text { use situationally to win a } \\
\text { specific customer. }\end{array}$ & Partial \\
\hline $\begin{array}{l}\text { Price } \\
\text { setting }\end{array}$ & $\begin{array}{l}\text { Complex/sophisticated } \\
\text { methods to customize prices. } \\
\text { Integrate with other tactics \& } \\
\text { supply chain. Flexible to } \\
\text { adapt to changes in } \\
\text { environment. }\end{array}$ & $\begin{array}{l}\text { Fairly standardized methods } \\
\text { used - simple and easy to } \\
\text { understand. Prices differ } \\
\text { because all projects differ. }\end{array}$ & No & $\begin{array}{l}\text { Standardized method used } \\
\text { but prices differ because } \\
\text { of different service levels } \\
\text { - simple \& easy to } \\
\text { understand. }\end{array}$ & No \\
\hline $\begin{array}{c}\text { Innovation } \\
\text { in pricing }\end{array}$ & $\begin{array}{l}\text { Novel/unexpected pricing, } \\
\text { including price differentials, } \\
\text { payment schemes \& discount } \\
\text { structures }\end{array}$ & $\begin{array}{l}\text { Standardized methods used, } \\
\text { so not innovative. }\end{array}$ & No & $\begin{array}{l}\text { Does use innovative } \\
\text { methods to cope with new } \\
\text { market requirements }\end{array}$ & Yes \\
\hline $\begin{array}{c}\text { Price } \\
\text { premium }\end{array}$ & $\begin{array}{l}\text { Get price premiums via } \\
\text { customer's inability to assess } \\
\text { costs, quality and value as } \\
\text { basis for negotiation. }\end{array}$ & $\begin{array}{l}\text { Get a price premium because } \\
\text { offer high product value. }\end{array}$ & Yes & $\begin{array}{l}\text { No premium - often must } \\
\text { accept negotiating price } \\
\text { down to get sales }\end{array}$ & No \\
\hline $\begin{array}{c}\text { Price } \\
\text { leadership }\end{array}$ & $\begin{array}{l}\text { Lead the market in initiating } \\
\text { price changes, price-cutting } \\
\text { and generally different pricing } \\
\text { policies. }\end{array}$ & $\begin{array}{l}\text { Not price leader - prices } \\
\text { determined by principals and } \\
\text { the market. }\end{array}$ & No & $\begin{array}{l}\text { Not price leader - prices } \\
\text { determined by market } \\
\text { practices. }\end{array}$ & No \\
\hline $\begin{array}{c}\text { Importance } \\
\text { of pricing }\end{array}$ & $\begin{array}{l}\text { Important because of its } \\
\text { visibility \& ability to } \\
\text { stimulate word-of-mouth \& } \\
\text { communicate messages to } \\
\text { market }\end{array}$ & $\begin{array}{l}\text { Not seen as an important } \\
\text { tactic to be used proactively to } \\
\text { effect the market }\end{array}$ & No & $\begin{array}{l}\text { Not seen as an important } \\
\text { tactic to use proactively to } \\
\text { effect the market }\end{array}$ & No \\
\hline
\end{tabular}

\section{Proposition 1}

Although the empirical findings and the summary in Table 2 show that CAs do not generally use pricing aggressively, they do price aggressively if trying to win specific business. CAs' prices do differ amongst customers, 
but their price-setting method is generally standardized and relatively simple. Although not a price leader, CAs do obtain price premiums for their products. In other words, pricing tactics are situationally determined - mostly maintaining a stabilizing approach, but prepared to destabilize when the situation demands it. From this discussion, it can be seen that CAs' pricing tactics generally involve some destabilization. Although their pricing is not exactly as per Model 1, there are some similarities to indicate partial support for Proposition 1; namely, a more successful firm in a complex/turbulent environment will use destabilizing pricing tactics but only in some situations.

\section{Proposition 2}

Although CBs are prepared occasionally to price aggressively and are reasonably innovative in pricing, their pricing tactics overall tend to be more stabilizing. Price changes are instigated by suppliers, standardized pricing methods are used and, overall, a status quo type policy is followed. Therefore, Proposition 2 can be partially accepted; namely, that a less successful firm in a complex/turbulent market would tend to adopt stabilizing pricing tactics.

\section{Model 2 - Pricing Tactics For Simple/Stable Markets}

Less aggressive, follower-type tactics, with simple, standardized price setting methods, and prices often negotiated down by customers, are suggested by Model 2 for simple/stable markets. Grundy (1995) maintains conservative, status quo pricing should be followed in simple/stable environments. This approach is also implied by Nilson (1995) who suggests that a conservative every-day-low-price strategy requires stability in the market to be successful. In simple/stable environments, pricing can be standardized (Pitt et al., 1997). Smith et al. (1999) show that price premiums are rarely obtained, and Morris and Schurink (1993) found pricing according to the market rather than being a price leader. Furthermore, Priesmeyer (1992) supports this conclusion by maintaining that, in a stable market, firms should price within the boundaries of the product's attractor. Table 3 illustrates this model in columns 1 and 2. As specified in the propositions, the more successful firm in a simple/stable market (PA) and the less successful firm in a complex/turbulent (CB) market would tend to match Model 2 (propositions 2 and 3, respectively).

Table 3: Comparison Of Firms PA And PB Against Simple/Stable Environment Model

\begin{tabular}{|c|c|c|c|c|c|}
\hline \multicolumn{6}{|c|}{ More Success In Simple/Stable Environment } \\
\hline & Model 2 & Firm $P A$ & Match & Firm PB & Match \\
\hline $\begin{array}{l}\text { Aggressive } \\
\text { pricing }\end{array}$ & $\begin{array}{l}\text { Less aggressive, not used } \\
\text { as a proactive strategy. } \\
\text { Aiming at maintaining } \\
\text { status quo. }\end{array}$ & $\begin{array}{l}\text { Conservative pricing - use } \\
\text { to stabilize. Avoids price } \\
\text { cutting. }\end{array}$ & Yes & $\begin{array}{l}\text { Status quo pricing, not } \\
\text { proactively aggressive, but will } \\
\text { price cut in reaction to } \\
\text { competitors' actions. }\end{array}$ & Partial \\
\hline $\begin{array}{l}\text { Price } \\
\text { leadership }\end{array}$ & $\begin{array}{l}\text { Price follower. Does not } \\
\text { initiate price changes. }\end{array}$ & $\begin{array}{l}\text { Niche leader but price } \\
\text { change prompted by } \\
\text { supplier price changes. }\end{array}$ & No & $\begin{array}{l}\text { Follows market and changes } \\
\text { prices according to supplier price } \\
\text { chans. }\end{array}$ & Yes \\
\hline $\begin{array}{l}\text { Innovation } \\
\text { in pricing }\end{array}$ & $\begin{array}{l}\text { Standard pricing methods, } \\
\text { following the industry } \\
\text { techniques. }\end{array}$ & $\begin{array}{l}\text { Standardized methods, but } \\
\text { do lead the market in } \\
\text { setting standards }\end{array}$ & Partial & $\begin{array}{l}\text { Follows standard setting process } \\
\text { - some innovation in trying } \\
\text { different approaches when } \\
\text { costing a job. }\end{array}$ & Partial \\
\hline $\begin{array}{l}\text { Price } \\
\text { setting }\end{array}$ & $\begin{array}{l}\text { Follow standard, simple } \\
\text { pricing methods, few } \\
\text { variations. Not integrated } \\
\text { with other tactics. }\end{array}$ & $\begin{array}{l}\text { Fairly simple with a cost } \\
\text { based standardized } \\
\text { approach not flexible. }\end{array}$ & Yes & $\begin{array}{l}\text { Fairly complex - no } \\
\text { standardized prices, but based on } \\
\text { costs and processes. }\end{array}$ & No \\
\hline $\begin{array}{l}\text { Price } \\
\text { premium }\end{array}$ & $\begin{array}{l}\text { Premiums not obtained. } \\
\text { Customers often negotiate } \\
\text { prices down. }\end{array}$ & $\begin{array}{l}\text { Does get premiums, in its } \\
\text { niche. Prices not } \\
\text { negotiated down. }\end{array}$ & No & $\begin{array}{l}\text { Premiums obtained for niche } \\
\text { products but often have to } \\
\text { negotiate down to get a job. }\end{array}$ & Partial \\
\hline $\begin{array}{l}\text { Importance } \\
\text { of pricing }\end{array}$ & $\begin{array}{l}\text { Price important but only } \\
\text { to cover cost, achieve } \\
\text { profit - not for strategic } \\
\text { reasons. }\end{array}$ & $\begin{array}{l}\text { Less important because of } \\
\text { emphasis on value and } \\
\text { quality. }\end{array}$ & Yes & $\begin{array}{l}\text { Price seen as very important } \\
\text { because it sees its market as very } \\
\text { price oriented. }\end{array}$ & Partial \\
\hline
\end{tabular}




\section{Proposition 3}

The empirical results discussed previously emphasize that PAs mostly follow a stabilizing approach to pricing. They do not use price aggressively and try to educate the industry against price-cutting. Price-setting methods are fairly simple and standardized. Although PAs do get price premiums, they often also have to negotiate prices with customers. PAs tend toward being price leaders, but only in their specific niche market, generally having to follow major suppliers' price increases. Therefore, their pricing tactics match Model 2 fairly closely, and so Proposition 3 can be accepted; namely, that a more successful firm in a simple/stable market will adopt stabilizing price tactics.

\section{Proposition 4}

Pricing is not used aggressively by PB as was proposed; prices are only cut in reaction to competitors' pricing actions and the firm is a price follower, often having to negotiate prices downwards to obtain a job. Status quo pricing tactics are important to PB. There is a lack of pricing aggression and pricing is not used to destabilize the market. Although there are some minor uses of aggressive pricing tactics, PBs' pricing tactics are generally more stabilizing and tend to match model 2 quite closely. Therefore, Proposition 4 can mostly be rejected; namely, a less successful firm in simple/stable market does not adopt destabilizing price tactics.

\section{IMPLICATIONS FOR PRICING MANAGERS}

This research has provided some guidance to managers responsible for pricing on how to relate to a complex and turbulent external environment. These implications are important because the increased complexity and turbulence in the South African environment makes marketing more challenging today than in the past. Although some work has been done in South Africa on business as a complex adaptive system, virtually nothing has been done on pricing.

In a turbulent environment, being a price leader - changing prices and pricing methods - is suggested. Innovative pricing methods should be adopted to customize prices to suit specific customers. The firm should use pricing tactically, using price-cutting, innovative discounts or price promotions. These tactics must be integrated with the supply chain and the marketing mix to avoid merely starting a price war. Price cutting is easily matched, but an innovative new pricing system, integrated with the supply chain, is difficult to react to or copy.

\section{LIMITATIONS AND RECOMMENDATIONS}

\section{Limitations}

Since this was an exploratory study and a small sample was used, it is subject to the limitation that the findings are not necessarily representative of all firms in the sampled industries, nor are they necessarily representative of other environments. Furthermore, the use of maximal variation sampling makes it difficult to draw definitive conclusions about other industries. In other words, the degree of variation between other industries might be more, or less, significant; therefore, it might be inaccurate to try to apply these findings to other industries. Therefore, if extrapolation of the results to other industries is attempted, it should be done with extreme caution.

\section{Recommendations For Further Research}

Resolution of the above problems and expansion of knowledge of pricing tactics could be achieved through successful research in some of the following areas:

- $\quad$ Similar research, but in a wider range of firms and in different industries, could test whether the findings of this study can be generalized to other industries and countries.

- $\quad$ Quantitative research focusing on a specific industry could be very helpful in more clearly differentiating the pricing tactics of more successful from less successful firms.

- $\quad$ More detailed research into individual pricing activities, from a complexity perspective, could throw light 
on their role in stabilizing or destabilizing the market and on their influence on marketing success.

- A longitudinal study following the trajectory of a pricing tactic to study the effect of sensitive dependence on initial conditions could confirm whether complexity theory truly helps in understanding pricing actions.

\section{CONCLUSION}

According to the literature, to be successful in a complex/turbulent market, a firm must be a price leader, setting the pace in changing prices and pricing methods. Innovative pricing methods should be adopted and the firm should be prepared to use pricing aggressively. This can involve price-cutting, innovative discounting or price promotions. This study has shown some support for this view, but it has also questioned whether the relationship between these destabilizing tactics and the nature of the environment is also related to success. Therefore, it is important that such tactics be implemented with care and integrated with other aspects of the marketing mix and of the supply chain.

\section{AUTHOR INFORMATION}

Roger Mason is an Honorary Research Professor in Marketing, Durban University of Technology, South Africa. He obtained a PhD from Rhodes University and an MBL degree from UNISA. He lectures and researches in the fields of marketing, management and retail, with special interest in the use of chaos and complexity theories in these fields. His background includes the motor industry and consultancy in a variety of industries. He has presented papers at international conferences and published in international journals. Email: e-mail: rogerm@dut.ac.za.

\section{REFERENCES}

1. Bright, J. K., Kiewell, D., \& Kincheloe, A. H. (2006). Pricing in a proliferating world. McKinsey \& Company. Retrieved from: www.mckinsey.com/insights/marketing_sales/pricing_in_a_proliferating_world.

2. Burgess, S. M. (1998). The New Marketing: Building strong marketing strategies in South Africa today. Halfway House: Zebra Press.

3. Chen, B., \& Ma, J. (2013). Study on the Complexity of Closed-loop Supply Chain Based on Price Difference between New and Remanufactured Products. Advanced Journal of Food Science and Technology, 5(12), 1566-1572.

4. Doherty, N., \& Delener, N. (2001). Chaos Theory: Marketing and Management Implications. Journal of Marketing Theory and Practice, Fall, 9(4), 66-75.

5. Dolan, S. L., Garcia, S., \& Auerbach, A. (2003). Understanding and Managing Chaos in Organisations. International Journal of Management, 20(1), 23-35.

6. Eugster, C. C., Kakkar, J. N., \& Roegner, E. V. (2000). Bringing discipline to pricing. McKinsey \& Company. http://www.mckinsey.com/insights/marketing_sales/bringing_discipline_to_pricing. [Accessed 25/7/2013].

7. $\quad$ Flick, U. (1998). An Introduction to Qualitative Research. London: Sage.

8. Gerschberger, M., Engelhardt-Nowitzki, C., Kummer, S., \& Staberhofer, F. (2012). A model to determine complexity in supply networks. Journal of Manufacturing Technology Management, 23(8), 1015-1037.

9. Grundy, T. (1995). Destroying Shareholder Value: ten Easy Ways. Long Range Planning, 28(3), 76-83.

10. Hibbert, B., \& Wilkinson, I. F. (1994). Chaos Theory and the Dynamics of Marketing Systems. Journal of the Academy of Marketing Science, 22(3), 218-233.

11. Holbrook, M. B. (2003). Adventures in Complexity: Dynamic Open Complex Adaptive Systems, Butterfly Effects, Self-Organizing Order, Coevolution, the Ecological Perspective, Fitness Landscapes, Market Spaces, Emergent Beauty at the Edge of Chaos, and All That Jazz. Academy of Marketing Science Review, 6. Retrieved from: www.amsreview.org/articles/holbrook06-2003.pdf.

12. Jager, W. (2007). The four P's in social simulation, a perspective on how marketing could benefit from the use of social simulation. Journal of Business Research, 60, 868-875.

13. Jensen, R. V., \& Urban, R. (1984). Chaotic price behavior in a non-linear cobweb model. Economics Letters, 15, 235-240.

14. Joubert, D. (1998). Competitive Firms Thrive on Instinct. Cape Town: Queillerie. 
15. Kelly, S., \& Allison, M. A. (1999). The Complexity Advantage: How the Science of Complexity Can Help Your Business Achieve Peak Performance. New York: BusinessWeek Books.

16. Khouja, M., Hadzikadic, M., Rajagopalan, H. K., \& Tsay, L-S. (2008). Application of complex adaptive systems to pricing of reproducible information goods. Decision Support Systems, 44, 725-739.

17. Kř́žz, R., \& Kratochvil, Š. (2014). Analyses of the Chaotic Behavior of the Electricity Price Series. ISCS 2013: Interdisciplinary Symposium on Complex Systems, Vol. 8, Springer Berlin Heidelberg, 215-226.

18. Kumar, N., Scheer, L., \& Kotler, P. (2000). From Market Driven to Market Driving. European Management Journal, 18(2), April, 129-141.

19. Ma, J., \& Chen, B. (2014). The Complexity Uncertain Analysis about Three Differences Old and New Product Pricing Oligarch Retailers Closed-Loop Supply Chain. Abstract and Applied Analysis, 2014, 11 pages.

20. Macias, M., \& Guitart, J. (2011). A Genetic Model for Pricing in Cloud Computing Markets. SAC '11, Taichung, Taiwan, March, 21-25.

21. Manuj, I., \& Sahin, F. (2011). A model of supply chain and supply chain decision-making complexity. International Journal of Physical Distribution \& Logistics Management, 41(5), 511-549.

22. Mason, R. B. (2004). An investigation into how marketers cope with an environment of high complexity and turbulence, with special reference to the South African environment. Unpublished PhD thesis, Rhodes University, Grahamstown, South Africa.

23. Meade, P. T., \& Rabelo, L. (2004). The technology adoption life cycle attractor: Understanding the dynamics of high-tech markets. Technological Forecasting and Social Change, 17, 667-684.

24. Mix, R. A. (1993). Is there chaos in marketing? Proceedings of Annual Summer Marketing Educators' Conference, American Marketing Association, 444-445.

25. Mohr, J. (2001). Marketing of High-Technology Products and Innovations. Upper Saddle River: Prentice Hall.

26. Morris, M. H., Marks, A. S., Allen, J. A., Peery, J. R., \& Newman, S. (1996). Modelling Ethical Attitudes and Behaviours Under Conditions of Environmental Turbulence: The Case of South Africa. Journal of Business Ethics, 15, 1119-1130.

27. Morris, M., \& Schurink, C. v. E. (1993). Pricing Behavior on Industrial Markets: The Impact of Environmental Dynamics. The Journal of Business and Industrial Marketing, 8(3), 28-43.

28. Morrison, D. J., \& Quella, J. A. (1999). Pattern thinking: Cutting Through the Chaos. Marketing Management, 8(4), Winter, 1-7.

29. Nilson, T. H. (1995). Chaos Marketing: How to win in a turbulent world. London: McGraw-Hill.

30. Pitt, L. F., Berthon, P. R., \& Morris, M. H. (1997). Entrepreneurial Pricing: the Cinderella of marketing strategy. Management Decision, 35(5), 1-8.

31. Priesmeyer, H. R. (1992). Organizations and Chaos: defining the Methods of Nonlinear Management. Westport: Quorum Books.

32. Roberts, J. H. (2000). Developing New Rules for New Markets. Journal of the Academy of Marketing Science, 28(1), Winter, 31-45.

33. Samli, A. C. (1993). Counterturbulence Marketing: A Proactive Strategy for Volatile Economic Times. Westport: Quorum Books.

34. Schiller, Z., Burns, G., \& Miller, K. L. (1996). Make It Simple: That's P \& G's new marketing mantra - and it's spreading. Business Week, 9 September, 96-104.

35. Schindehutte, M., \& Morris, M. H. (2001). Pricing as Entrepreneurial Behavior. Business Horizons, JulyAug., 41-48.

36. Smith, M. F., Sinha, I., Lancioni, R., \& Forman, H. (1999). Role of Market Turbulence in Shaping Pricing Strategy. Industrial Marketing Management, 28, 637-649.

37. Stacey, R. D. (1995). The science of complexity: An alternative perspective for strategic change processes. Strategic Management Journal, 16, 477-495.

38. Stacey, R. D. (1996). Complexity and Creativity in Organizations. San Francisco: Berrett-Koehler.

39. Van der Walt, A., Strydom, J. W., Marx, S., \& Jooste, C. J. (1996). Marketing Management. Kenwyn: Juta.

40. Weeks, R. V. (2007). Context: The strategic management Rosetta stone. Acta Commercii, 7: $294-306$.

41. Wu, Y., \& Zhang, D. Z. (2007). Demand fluctuation and chaotic behaviour by interaction between customers and suppliers. International Journal of Production Economics, 107, 250-259. 
42. Yin, R. K. (2003). Case Study Research - Design and Methods, 3rd ed. Beverly Hills, CA: Sage Publications.

43. Zaib, N. A. M., Bazin, N. E. N., \& Mustaffa, N. H. (2013). Exploratory study on the effect of discount pricing strategies for new product introduction. In Proceedings of the 20th National Symposium on Mathematical Sciences: Research in Mathematical Sciences: A Catalyst for Creativity and Innovation, 1522(1), 720-726). 